Article

\title{
The Impact of Sanctions and Neo-Liberalism on Women's Organising in Iran
}

\section{Tara Povey}

School of Oriental and African Studies, The University of London, London WC1E 7HU, UK; tp24@soas.ac.uk; Tel.: +44-207-898-4757

Academic Editor: Nancy Naples

Received: 11 January 2016; Accepted: 17 June 2016; Published: 23 June 2016

\begin{abstract}
As in the case of many contemporary movements, Iranian women's activism is connected into local, international and transnational politics. However, Iranian women's views of transnational solidarity and perceptions of foreign support for women's rights in Iran are complicated by the experience of Western foreign policy of the last three decades. This is perceived to have claimed to support women's rights and liberalism against what is often described as a "conservative theocratic state" but has, in some ways, made it more difficult for women to organise "on the ground" and strengthened the hand of conservative forces both materially and ideologically. Two facets of Western foreign policy towards Iran will be discussed and analysed in relation to their impact on women; firstly, this article will investigate the impact of sanctions and the international isolation of the country since 1979 on women's organisations. Secondly, it will analyse neo-liberalism and the changing nature of the Iranian state, as well as political elites. Utilising interviews with Iranian women activists conducted in 2009, in addition to April 2015, the article will discuss views of transnational solidarity and the diverse political strategies utilised by women activists and organisations in Iran today.
\end{abstract}

Keywords: Iran; women; transnational politics; activism; sanctions; neo-liberalism

\section{Introduction}

In this article, I analyse the impact of sanctions and neo-liberalism on perceptions of transnational solidarity and foreign support among Iranian women activists who are working in diverse organisations, such as the One Million Signatures Campaign, the Stop Stoning Forever Campaign, and Mothers for Peace. Iran has faced international isolation following the US embassy occupation in 1980, and sanctions were enacted against the country in 2006 as a result of its nuclear programme. Some important sanctions were lifted in 2016 as a result of the 2015 nuclear deal, however non-nuclear sanctions remain in place, which are aimed at punishing Iran over its record on human rights and its support of terrorist organisations. Despite facing international isolation, Iran has been a member of major international organisations and has undertaken neo-liberal policies since the end of the 1980s at the behest of the International Monetary Fund (IMF) and World Bank. I argue that the combination of international isolation, sanctions and neo-liberalism has produced a more coercive, clientelistic and securitised Iranian state, has increased poverty and inequality in the country and has made it more difficult for women's groups to organise. The lived experience of these policies means that Iranian women activists have a complex and critical attitude towards foreign support and the benefits and challenges posed by the forging of transnational linkages.

The women's movement in Iran is a diverse movement encompassing activists from differing political backgrounds, both secular and religious. Groups contain activists from a range of different political backgrounds such as leftist, nationalist, reformist and Islamist. Many activists do not easily fall into boundaries of secular/religious and in fact rather than seeing them as monolithic and mutually exclusive positions, activists in different groups have articulated a range of perspectives that highlight 
the commonalities between secular and religious political frameworks as well as the divergent positions that can be taken within each. Similar to other contemporary social movements, several groups within the Iranian women's movement have been connected into and influenced by transnational politics. This has been documented by writers, such as Nayereh Tohidi and Valentine Moghadam, who have researched Iranian women's groups' participation in international conferences, their activism and campaigns around the implementation of international conventions on women's rights and human rights, such the UN's Convention on the Elimination of All Forms of Discrimination against Women (CEDAW), and the role played by the diaspora [1,2]. These works have been immensely useful in documenting women's involvement in transnational organisations and networks. However, on the whole these writers tend to present an uncomplicated picture of women's participation, which focuses on the benefits that women's groups gain from their interactions with institutionalised, top-down and hierarchical feminist organisations and the ways in which they receive support and recognition in the West. This has been accomplished through focusing on high profile international campaigns such as The One Million Signatures Campaign launched in 2006, which became something of a cause célèbre outside Iran and the work of specific Iranian activists living outside the country, such as Shirin Ebadi, Iran's most prominent female lawyer and women's rights activist, who was awarded the Nobel Peace Prize in 2003.

Women's groups and organisations have accomplished a great deal through their work with transnational feminist groups in campaigns around issues such as the death penalty, adultery, stoning and perhaps most significantly, the One Million Signatures Campaign. However, in this article, I go beyond documenting these links in order to investigate the politics of transnational cooperation and some of the challenges presented by the international political environment. I argue that women's criticisms of transnational cooperation are not due to hostility on the part of women's organisations to Western organisations or to the idea of foreign support. Neither are they seeking to defend local or indigenous concerns or feminisms against that of a globalising Western movement. Indeed, I resist a binary model that posits a neat separation between a local/authentic and global/transnational politics ([3], p. 279). The presence and importance of the diaspora in Iranian politics and movements is testament to the fact that Iranian women's organisations have a long history of interacting with transnational networks. As Nayereh Tohidi notes, the activities of the diaspora include raising international awareness, providing financial support, sending in literature and organising international forums and conferences in which activists and campaign groups gain visibility and legitimacy ([4], p. 224). In 1999 there were an estimated 97 Iranian women's groups outside Iran in Europe, North America, Asia and Australia ([4], p. 223). Iranian women activist's views of transnational solidarity are not therefore due to the insularity of organisations or political outlooks but to the lived experience of Western foreign policy in the country and the region.

\section{Women's Activism, Sanctions and Neo-Liberalism}

\subsection{The Research}

My analysis is based on fieldwork I conducted in Iran in 2008, 2009 and 2015 where I interviewed twenty nine activists involved in women's groups, reformist organisations, journalists, academics, leaders of non-governmental organisations (NGOs) and worker and student activists. In 2008-2009 I interviewed thirteen women and seven men who were involved in reformist, women's and pro-democracy organisations, groups and NGOs. They were identified through personal connections and networks and occupied public positions in political parties, groups, NGO's and campaigns. As public figures they were very familiar with the concept of research and at that point were happy to be interviewed and for their personal identifying information to be revealed. I asked a series of open-ended questions about the opportunities and challenges they faced as activists and our discussions were dominated by the responses of women and reformist activists to the Ahmadinejad 
administration (elected to office in 2005), the impact of the sanctions regime and military threats against Iran.

In 2009, the situation inside the country changed dramatically as a wave of repression of social movements followed the disputed presidential election of 2009 and the rise of the Green movement. Six of the activists who I interviewed after June 2009 had left the country for Europe or the US. Some continue to be involved in politics through social media or as a specific part of a diaspora that is far from politically homogenous. In April 2015 I conducted fieldwork with nine activists, six women and three men. Two of the participants were activists whom I had interviewed in 2008-2009. However, four of the women and two men were from similar social milieus and were engaged in similar political work as those I interviewed in 2009. In both cases they were veterans of long-standing women's organisations, previous political administrations and movements including the 1979 revolution and the reform movement of the 1990s. They identified with a range of political opinions such as Islamic reformist, leftist and nationalist.

In 2015, I also interviewed three young activists working in the arts who had been active in more recent movements including the Green movement of 2009. As in 2008-2009, these were semi-structured interviews with public figures who were familiar with the concept of research and in the opening questions I asked the participants about their views of the changes engendered in Iranian society by the neo-liberal reforms of the past decade and the impact that these had on movements and on women's lives. It was clear that in the intervening six years the concerns of activists had shifted from being focused purely on democracy and human rights to encompassing broader issues of social and economic inequality. For example, a number of activists who had supported the neo-liberal economic programmes of reformist administrations led by presidents Khatami (1997-2005) and Rouhani (2013-current) now expressed concerns about the impact of privatisation and cuts to state welfare programs on women and the empowerment of new military-business elites. Additionally apparent was the extent to which the strategies of contemporary movements are influenced by activists' perceptions of the role of women in Iran and in the international arena as well as the politics of their participation in previous movements, which I discus in the following section.

\subsection{Iranian Women's Activism in a Historical Context}

The Iranian women's movement has been the subject of considerable scholarly attention and its importance as a movement has been widely analysed both in the Middle East and globally [5-9]. Its significance within the country is exemplified by the fact that since the 1990s, the movement has successfully challenged the exclusivist and patriarchal nature of the state and reformed over twenty laws in favour of women ([9], p. 101). Despite Iran's international isolation since the 1979 revolution removed the Western-backed Shah from power, women inside Iran have more rights than in neighboring US-backed states in the Gulf. Empirical data that can be gathered on Iranian women shows that their literacy levels are very high compared to other countries in the region- $96 \%$ in 2004-2008 ([10], p. 40), and in 2010 and 2011 they made up 60\% of students who participated in the national examination to be accepted into universities ([11], p. 37). Similar to other Middle Eastern countries, despite being highly educated, women are still a minority in the formal economy- $10 \%$ in manufacturing industries and 35\% of government employees [10]. However, they play an important role in the informal economy including in the money market and the property market [10]. Women have also been impacted by the growing levels of poverty and income inequality in Iran since the 1990s. Most analysts agree that unemployment, particularly among youth and women, has risen and the cost of living has increased exponentially due to sanctions and economic policies. Youth unemployment is estimated at $28.30 \%$ and female unemployment is among the worst in the region ([12], p. 16).

Historically, women have played a major role in social movements in Iran. Since the late 19th century, women have been at the forefront of modern mass national movements against authoritarianism and in favour of democracy, gender rights and national independence [13,14]. Women played a highly significant role in the 1979 revolution, where their participation was crucial in bringing 
down the Shah's regime and was praised by revolutionary leaders ([13], p. 67; [14], p. 303). This is often obscured by analyses of the revolution that present it as a return to traditionalism and fanatical religiosity. The revolution empowered a generation of working class and middle class women in Iran and the new state provided them with both 'material and ideological resources' ([9], p. 136). For example, campaigns of Islamisation and gender segregation undertaken by the new state encouraged women's participation in the workforce in certain areas, which had previously been dominated by men, which eventually led to an increase in women's participation in the labour force and in education ([15], p. 78; [16], p. 187).

Islamisation of society also made female employment and schooling acceptable to women from socially conservative families who had been discouraged from entering the workforce during the shah's regime ([9], p. 136). While many women were purged from their professional roles due to the closure of universities, mandatory wearing of the hijab and gender segregation, religious women found previously male-dominated environments open to them. Despite the fact that leaders of the revolution expressed gratitude to women, the new policies of the state also aimed at demobilising the forces of the revolution including movements of women, workers and national minorities and introduced laws restricting women's rights. However, at the same time, women who had participated in the revolution benefited from the mass social welfare campaigns enacted in the 1980s and demanded to be fully involved in the political, economic and social life of the country.

At the end of the 1980s a diverse women's movement arose which included the articulation of a variety of strands of Islamic feminisms. These were opposed to the westernising state feminism of the Shah's regime and presented a radical challenge to political elites within Iran who justified state policies on the basis of an exclusionary interpretation of Islamic jurisprudence. For example, campaigns around custody of children and women's rights to act as judges and to hold the position of president of the republic were framed as 'Islamic rights' that could not be withheld by the state ([13], p. 68). Campaigns were often led by daughters of the major public intellectuals of the revolution, such as Farideh Mostafavi (daughter of Ayatollah Khomeini), Azam Taleghani (daughter of Ayatollah Taleghani) and Faezeh Hashemi (daughter of ex-president Rafsanjani). These activists not only pressed for gender equality, but presented a challenge to the power structure that was firmly grounded within the legacy of revolutionary radicalism of the 1970s. A number of writers have noted that initially groups and individuals that advocated for Islamic and indigenous feminisms were hostile to secular feminists both within and outside the country $[9,17]$. This did not denote hostility to secularism per se, as most political activists, particularly those from politically-involved families were familiar with and had a sophisticated understanding of both Islamic and Iranian history and the work of major secular and leftist thinkers. Instead this was partly a reaction against westernising state feminism enacted by the dictatorial regime of the Shah and also part of the rejection of Western foreign policy and imperialism that characterised the movements of the 1970s.

In 2006, a number of campaigning organisations were established by Islamic and secular feminists, reformists, human rights activists, and civil society activists in Iran. It is important to note that the membership of these campaigning groups and organisations has changed substantially since their founding and remains very fluid. The One Million Signatures campaign was formed with the aim of ending discriminatory laws against women. Its membership included women from a variety of backgrounds, both political and religious. Despite facing a number of challenges, including political differences and pressures from the state the organisation was effective in opposing the passage of the "Family Protection Act" under the presidency of Mahmoud Ahmadinejad. It also pressured the reformist candidates Mir Hossein Musavi and Mehdi Karrubi, to appoint women ministers and to support ratification of CEDAW [18]. The organisation gained considerable public attention outside Iran, winning the Simon de Beauvoir award, the Feminist Majority Foundation award and becoming "Glamour" magazine's "women of the year" in 2009 [19].

The Campaign to Stop Stoning Forever was founded to abolish stoning as a criminal punishment and with the aim of finding cases and freeing convicts [20]. It has involved Iranian lawyers, such 
as Shadi Sadr, and has led to the overturning of six convictions [21]. Additionally founded in 2006, Mothers for Peace is a campaign with approximately 700 participants from diverse political backgrounds and different social classes who stand against any form of violence, poverty, and oppression. The organisation played an important role in opposing sanctions against Iran arguing in 2013 that sanctions were "victimizing the very fabric of the society we intend to strengthen" [22]. The three organisations whose work is outlined here are among those who have been at the forefront of the women's movement in the past decade and have garnered international attention and in some cases, considerable foreign support. It is therefore possible to analyse the views of activists connected with them as a window into some of the debates that have taken place on international cooperation, its benefits and challenges, and as a corrective to the kinds of analyses that present an uncomplicated picture of international feminist solidarity.

\subsection{Transnational Solidarity and International Politics}

The early 2000s were a high point for international and transnational movements. Anti-capitalist movements such as the World Social Forum brought together activists from many different parts of the world to protest against corporate globalisation and in 2003, anti-war movements organised the largest coordinated global protests in the run-up to the invasion of Iraq. By the late 1990s, a number of studies had begun to analyse the role and impact of transnational advocacy networks and the ways in which women's movements, environmental movements and others forged transnational links, in order to gain resources, ideas and opportunities for political action [2,3,23,24]. Defining transnationalism involves considering what constitutes local, sub-national, national, international and transnational political action. Donatella della Porta and Sidney Tarrow, for example, define transnational collective action as "coordinated international campaigns on the part of networks of activists against international actors, other states or international institutions." ([25], pp. 3-4). Transnationalism is also related to and sometimes seen as the outcome of 'internationalism', which, Tarrow argues, denotes "deepening interstate relations and increasing international economic integration" ([26], p. 8). Tarrow conceptualises transnational actors as non-state actors who are responding to the opportunities and threats presented by internationalism ([26], p. 12). In the majority of accounts, transnationalism has been seen as a product of globalisation and new opportunities presented by global information flows, movements of people, the opening up of trade barriers and the spread of social media [27]. Globalisation has also engendered a debate about the potential and problematics involved in international feminist solidarity. For example, Sally J. Scholz argues that, "globalisation not only expands the reach of business across borders or transnationally but also expands politics. Transnational feminist solidarities make use of the tools of globalised communication and politics in building networks for action in political solidarity" ([28], p. 207). However, the link between transnationalism and globalisation has, too often, been imagined by scholars of social movements as a one way process in which the 'liberal' ideas of individual freedom, empowerment and emancipation originate in the West and are exported through globalisation to the rest of the world. Non-Western societies are seen as dominated by "ugly movements", which Tarrow describes as linked to extremism, ethnic and nationalist exclusivism and terrorism ([29], p. 9). This approach is problematic as it ignores the capacity for change that lies within non-Western societies, viewing Westerners as the only "actors" on the global stage who change history. It also ignores the culpability of Western governments who often play a role in sustaining undemocratic regimes and fostering conservative movements.

Post-colonial and feminist scholars have problematised the construction of binary oppositions between Western organisations whose politics are assumed to be universal and non-Western organisations, which are presented as rooted, authentic and localised or grassroots [30-34]. Judith Butler, for example, offers a critique of the assumption that the concerns of Western social movements are "universal" when the concept of "universality" is in of itself a product of a specific historical and geographic locality ([30], p. 35). Kaplan further argues that the politics of location should not be presented as a "reflection of authentic, primordial identities", a framework that remains locked into the 
conventional oppositions between what is "global" and what is "local" and furthers the construction of binaries between the "West" and the "East" ([33], p. 139). Instead she builds on the work of Elspeth Probyn [34] to show that what is seen as "local" and "universal" politics signify an aspect of location in a specific time and place ([33], p. 149) and crucially a set of practices that have both conformist and transformative potential.

It is important to note that transnational politics cannot be separated from the international political situation and the specific opportunities as well as challenges presented by the internationalisation of the global environment. Maha Abdelrahman, for example, provides an analysis of the impact of international politics on views of transnational linkages in Egyptian social movements. In her article on the Egyptian Anti-Globalisation Group (AGEG) and its links with the Global Justice Movement (GJM), Abdelrahman argues that transnational links can play a vital role in strengthening movements as activists build links and gain strategies, resources and solidarity from outside the country. According to her analysis transnational networks played a role in "creating a new political sphere that had potential for social and political transformation and where new identities could be developed and new demands articulated" ([35], p. 421). However, Abdelrahman also suggests the limits of possibilities for transnational activism and the potential pitfalls of becoming reliant on "international solidarity". The issue of external funding is particularly controversial in the Middle East. As Abdelrahman writes: "Official links between NGOs and other civil society groups and global financial institutions and bilateral donors since the 1980s have opened up further debates on the political nature of foreign funding and reinforced a discourse of distrust of links with global forces" ([35], p. 419).

International solidarity does not only involve West-East but also South-South collaborations. However, it is also the case that Western countries, due to their economic and political power exercise a more important place in terms of international support, particularly when it comes to funding, than groups originating in other parts of the world. The fact that international solidarity, in the form of gaining actual resources from the West has proved to be more controversial in the Middle East than the idea of building activist links across borders, is due not only to the concerns outlined above but to the experience of Western foreign policy in the region. Neo-liberal globalisation, which some theorists argued would produce a "flat world" dominated by liberal capitalism have, in many cases led to the strengthening of repressive regimes in contexts such as the Middle East-a process that has been facilitated by Western governments [13]. This reality of increased support for authoritarianism lies beneath the funding of civil society from the 1990s onwards which was accompanied by the rhetoric of the "democracy promotion" agenda. Therefore, Middle Eastern activists are cautious about accepting funding from Western sources lest they be seen as complicit with national and international bodies that have funded and supported military dictatorships in the region.

Western aid and military interventions from the 1990s onwards were also based on a discursive and ontological separation between Western and Middle Eastern societies that presented non-Westerners as backwards, anti-modern and fundamentalist. In this context the "liberal" ideas of women's rights, sexual and gender rights were utitlised to further a neo-imperialist strategy and several wars were conducted in the region on the basis of "saving women" [36,37].

Transnational solidarities are different from international political pressures, sanctions, wars, occupations, and economic impositions. However, transnational politics takes place against the backdrop of the international political context and the presence of these pressures complicates the practices of international feminist solidarity at material, strategic and discursive levels. There is a growing body of scholarship on the politics of organisations that campaign around issues of gender and sexuality [38,39], as well as that which analyses the histories of sexuality and sexual identities in Iran and the Islamic world [40-42]. Joseph Massad argues that the activities of the "gay international", which consists of groups and organisations that originate in the West, has enforced a West-centric binary model of sexual identity that has made it more difficult for individuals and sexual-rights organisations to organise in the Middle East. In the context of Arab nationalist/Islamist 
anti-colonialism, Massad states that the activities of Western gay-rights organisations are rightly perceived as part of Western encroachment on Arab and Muslim culture ([39], p. 375). His critique also raises questions about the funding of such international solidarity campaigns, pointing to the fact that Gay rights organisations rely on funding from the same institutions that advance the US's imperial interests and that unsubstantiated reports of mass executions of homosexuals in Iran were used to justify US foreign policy towards that country ([39], p. 363).

International politics has a complex impact on specific groups that take part in transnational movements at different levels. Transnational links connect them into political networks and ideological frameworks, which provide opportunities for action. However foreign support can also make them vulnerable to political demands that can sit uneasily with their aims and objectives as political activists and as organisations. The Iranian women activists I interviewed expressed a complex relationship with international solidarity that did not originate in a defense of the local against a globalised politics, but was enmeshed in transnational politics and took place against the backdrop of the international political context.

In 2009 the One Million Signatures campaign won a prestigious international award for women's rights, the Simone de Beauvoir award, which was to be presented to a representative of the campaign in Paris. The awarding of the prize, alongside a significant financial donation, sparked an intense debate within the organisation in Iran. Accepting the financial award could make the organisation vulnerable to accusations that they were working with foreign sources against the government, a charge that is commonly used to shut down women's and pro-democracy groups and arrest their members. There was also a great deal of unease about the ethics of accepting the award, which centered on the members' political positions regarding regional and international concerns. At the end of 2008, the Israeli army had launched a catastrophic bombing campaign in Gaza, which Iranians watched like people all over the region on Aljazeera via satellite with feelings of mounting horror. By early January, the Israeli army mounted a ground offensive which led to casualties and deaths of Palestinians living in the Gaza strip on a horrific scale and which in September 2009 was condemned in a report by the UN as a "war crime". After a brief period of relative optimism following the election of President Barak Obama in the US, this period was dominated politically by these events. Mass demonstrations took place in Tehran, Cairo and in many cities across the region and across the world. In 2009 I interviewed an activist who was one of the first involved in setting up the One Million Signatures campaign. This activist described the work of the organisation in Iran as follows:

I was amongst the first 54 people who organised the One Million Signatures campaign. The campaign's activities were around discriminatory issues against women. The aim was to collect one million signatures in order to change laws and regulations in favour of women and to raise women's awareness about different forms of discriminations against women.

She told me that regional and international political events lay behind the debate about the prize and highlighted the importance of financial independence from the state and foreign donors to the organisation:

We consider this campaign a civil society organisation and we believe that we should be independent of our own government and other institutions in Iran or outside of Iran. Therefore we try to rely on our own possibilities and capabilities, especially financially. To be independent is also important for us so that we can make better connections with ordinary people. When we receive funding we record it clearly in our website, stating where the money comes from and how much was donated.

Some in the organisation argued that their focus should be on women's rights and not on international issues, particularly as anti-imperialist rhetoric is often used to engender support for the state. Others argued that they should not accept the prize at all in order not to be seen as complicit in the actions of the US/Israeli government. These activists raised an additional concern that if someone 
was to travel to Paris to accept the award, they would potentially share the stage with and possibly be photographed shaking hands with US state officials, such as the then US Secretary of State Hilary Clinton, while the bombing in Gaza continued. This activist pointed out that having accepted the prize, "some of us in the campaign argued that we donate this prize to victims of Gaza."

This incident demonstrates the complexity of transnational solidarity in women's organising in Iran. Women activists who I interviewed in 2009 argued that their feelings towards accepting international solidarity were not influenced by hostility towards secular, western or foreign women's organisations, but by their concerns over being seen as complicit in Western foreign policy towards Iran and the Middle East in general. In 2009 I interviewed a prominent lawyer, journalist and women's rights activist, who described her work in the Stop Stoning Forever campaign and other organisations:

I first worked as a journalist when I was student in 2001. I wrote for different newspapers and journals and with a group of young activists we organised the celebration of 8th of March and other activities around women's rights issues. Later, I had a column in one of the newspapers and I regularly wrote on women's issues. I used to get telephone calls and emails from women asking for legal guidance so I decided to set up a centre for women in which we gave legal advice and guidance to women who needed help. The work of the centre was very successful. We had 40 voluntary workers working in the centre and many women came there for advice. We also had a network of activities with other women activists and we organised large demonstrations on women's issues...

...We began to work on particular issues such as the campaign against stoning to death. Although it was announced that stoning to death was officially abandoned, we heard reports that there had been a number of cases. So we began on work on this issue and succeeded in stopping a number of stonings. We also worked on the issue of women being allowed to go to a sports stadium to watch games alongside men, and on the rights of women to pass their nationality and citizenship to their children.

This illustrates the range of activities this activist's organisation was involved in, from organising celebrations of international women's day on 8 March, to publishing on women's issues, running a women's advice centre and campaigning against discriminatory laws. Those involved in the organisation worked hard to maintain independence from both government and outside funding. Despite their struggle to maintain this independence, they had to abandon all efforts at international solidarity after they were accused of receiving money from overseas:

We were accused of receiving money from outside of the country. So we stopped getting funding from outside and relied on the voluntary work of women in our organisation. We printed stamped post cards, addressed to the MPs and the Parliament, explaining about the laws and regulations which are against women's interest and demanded change of these laws and regulations and distributed these to the population. Many women signed and posted the cards to their MPs and we feel that this was a successful campaign.

A journalist and editor of a women's journal who I interviewed in Tehran in 2009 expressed that her organisation was in favour of building international solidarity and working with diverse women activists, both secular and religious. However, she stated that, in order to do this, Western activists would need to counter the negative portrayal of Iran, Islam and Iranian women in the media:

The foreign media have their own agenda about women and women's issues in Iran. We have tried to avoid labelling women and women activists and bringing diverse groups and individuals together in order to resolve women's issues. We began by arguing that the God, Islam and the Quran are against women's subordination and discrimination against women. Therefore, feminism is not contradictory to Islam. We also argue that we share a common fate with women around the world as there is no real equality between women and men anywhere in the world. Therefore the fight for women's rights is a global issue. 
Despite their criticisms of the politics of Western feminist organisations, the women I interviewed in 2008 and 2009 were engaged in transnational networks and viewed women's rights as a global issue. The argument that Islam and the Quran are in favour of women's rights, which this participant raises, is sometimes seen as an expression of indigenous, local values or criticised as cultural relativism ([43], p. xii). However, it is significant that this activist saw it as part of the challenges posed by working with Western groups and activists in the context of the international political environment.

\subsection{Sanctions, Neo-Liberalism and Women's Organising in Iran}

Women's views of transnational cooperation since 2009 have been influenced by the impact of two aspects of Western foreign policy towards Iran; sanctions and neo-liberalism. The lived experience of these policies has strengthened the view that women's groups and organisations should work independently of Western organisations and groups. The activists I interviewed argued that foreign policies, which purportedly encourage Iran to liberalise in the areas of human rights and women's rights were seen as part and parcel of a democracy promotion agenda utilised by Western governments who pursue an imperialist and militaristic policy in the Middle East. These had in fact hampered women's ability to organise and strengthened conservative forces in the country:

I believe that pressures from outside have always a negative impact on us. The more they put pressure on us, the more the conservatives become stronger. Wars and conflicts in Iraq and Afghanistan have united people in Iran against foreign intervention.

Sanctions also had an immensely detrimental effect on poor and working class Iranians while the rich and those with connections to the state actually benefited in some cases. In January 2013 Mothers for Peace wrote an open letter to Mr. Ban Ki-moon, the UN Secretary General, and Dr. Margaret Chan, the Director General of the World Health Organisation, alerting the responsible world bodies and human rights organisations to the critical shortage of vital medication due to the US/EU-led sanctions on Iran and their deadly impact on the lives and health of the Iranian population. In the letter they stated that, "we view the Western-imposed crippling sanctions on the people of Iran as a form of structural violence-a silent, yet a predatory war" [22]. During the decade of the 2000s sanctions were not the only obstacle to women's organising in Iran. Different women's groups faced many challenges from the conservative and anti-democratic nature of the state to their own internal weaknesses and lack of agreement on political strategy. However, international pressures worsened the already difficult position in which women found themselves and weakened their capacity to oppose the state.

The decades since the end of the 1980s in Iran were also dominated by neo-liberal economic policies, which included structural adjustment programs demanded by the World Bank consisting of mass privatisation of the public sector and the removal of trade tariffs and subsidies. It is important to note that neo-liberal policies have been applied differently in the countries in the Middle East. In the case of Egypt, which endured one of the earliest experiments with neo-liberalism, infitah or "open door" policies were first applied by the government of Anwar Sadat in the 1970s and were accompanied by a turn towards the West in foreign policy. Neo-liberalism in Egypt continued with many stops and starts but gathered pace after 2005 and became associated with exploitation of that country's material resources and labour force by multinational corporations originating in the West [44,45]. In Iran, neo-liberalism has been associated with reformist political administrations. Structural adjustment was first carried out by the Rafsanjani administration in the early 1990s and, as in other countries, has not been an overnight process but has been accompanied by policies that aimed to ensure the political survival and stability of the state. However, as in a number of other countries in the region, neo-liberal policies increased rapidly from the mid-2000s onwards under the presidency of Mahmoud Ahmadinejad who went as far as to amend the constitution in order to fully privatise the public sector.

Alongside sanctions, these economic policies have had an enormous impact on the lives of working class and middle class Iranians. As with elsewhere in the world, privatisation measures have caused rising unemployment and insecurity in the labour force, while the removal of subsidies have 
led to soaring prices of essential food items, medicines, fuel and other necessities. Women have been particularly affected by these policies. In Iran, as in other parts of the world, it is women who have entered the labour force in order to take up casualised and part-time work with no contracts and little job security. It is also women who bear the responsibility of acting as carers of the young, sick and elderly population. In 2015, I interviewed a range of women and men about their experiences of organising in the context of these economic and political changes. One woman film maker stressed the successes of the women's movement in Iran, in comparison with Western countries where women struggle to be accepted, stating that "Women in many Muslim majority countries are fighting for their rights today and are successful."

Similar to a number of other activists she argued that this was due to the important role that women played in the revolution and in other movements such as the reform movement of the 1990s. She stressed that the significant role women play today in the arts, politics and social life of the country is due to their own efforts and their own struggle to re-resist and re-interpret conservative and patriarchal laws in women's favour:

Young women in Iran have learnt how to fight for their rights, according to their culture. They have changed the society to accept their way of life. The way that young women wear the hijab [so that some hair is visible] is an example. Hijab was prescribed to be worn in a certain way [during the revolution] and now see how they wear it and it has become accepted! [by the state].

However, despite these achievements, the women I spoke to also felt that the neo-liberal reforms of the past thirty years, in addition to sanctions and Iran's international isolation, had made it harder for women to be active and to continue to resist. Neo-liberalism was seen in contradictory ways, as an ideology that held out the promise of reduced interference of the state in society-something many activists welcomed — but that resulted in a stronger more militarised state and political elite [46].

Women involved in the organisation Mothers for Peace and other groups argued that as a result of neo-liberalism, more people in Iran now live in poverty and work in precarious, underpaid employment or in the informal sector of the economy:

During Ahmadinejad the economic situation deteriorated. The GDP was reduced to -6 . The living standard of the people was reduced enormously, especially the poor got poorer but the rich got richer. According to the labour laws, workers should receive wages above inflation; although wages were increased to some extent, wage increases did not reach the high level of inflation.

In Iran, as in other countries that undertook neo-liberal policies, reforms did not lead to a smaller state but the economic empowerment of networks of elites with connections to the government. One activist described how the state run foundations set up after the revolution, such as the Basij ${ }^{1}$ and Revolutionary Guard ${ }^{2}$, became the beneficiaries of privatisation as Iran moved from a leftist to a neoliberal economic model:

The idea of socialism or communism was very influential in the 1979 revolution amongst all different groups. Even if some groups were hostile to the socialist or communist ideology, these ideals were very strong amongst all the people. The slogans of independence, not to be the slaves of capitalism and imperialism were very popular and were daily repeated. Then the Iran-Iraq changed this situation and the political situation deteriorated. The US

1 The "basij" (mobilisation) organisation was created as a volunteer paramilitary organisation during the 1979 revolution. Its social base is traditionally the urban and rural poor, particularly the generation who fought in the Iran-Iraq war.

2 The Islamic Revolutionary Guard Corps or "Revolutionary Guard" is a military organisation formed as a volunteer paramilitary force during the 1979 revolution. They are increasingly involved in economic and commercial activities. 
froze our assets and blocked our capital. This created a black market, and the Foundations became mafia type organisations. These Foundations were genuinely positive before the war and were helping and subsidising the poor, but after the war they became mafia type organisations which only worked in the interests of those who controlled them.

This process, in which the security apparatus of the state increases while social welfare programs, subsidies and the public sector are reduced is not unique to the Iranian experience but has been analysed with reference to other countries in the region and globally, as the development of national "security" states [13]. Neo-liberalism and the emergence of this type of national security state in Iran have empowered the IRGC or Revolutionary Guard, which now controls most important economic activities in the country ([47], p. 55). An activist in a women's organisation commented:

During Ahmadinejad's period the level of concentration of capital in the hands of the Revolutionary Guards and the level of privatisation increased enormously. The level of industrial production declined and services increased. The Revolutionary Guards took over nearly the whole of the private sector. In a way the private sector of the past ${ }^{3}$ was destroyed and a new one was created.

Another feature of neo-liberal reform has been the de-regulation of the banking sector and the rise of private banks. The nationalisation of banking was a key part of post-revolution economic policy. However, private banks were allowed to re-open in the early 2000s by the Central Bank. New banks have proliferated in the past few years with eight created in 2011 alone [48]. Many are affiliated with the Revolutionary Guard or Basij militia and form a sector of the economy that is neither part of the private sector nor the state. The booming banking sector does not however represents growth in the economy, rather the proliferation of "non-performing" loans to the poor and real estate speculation which one interview participant described as the business of "selling air", as the majority of new buildings are high-rise apartment complexes.

The impact of these policies has presented great challenges for women in Iran and have influenced their views of the possibilities of transnational cooperation. The women and men I interviewed stressed that positive changes and reforms could only be brought by Iranian women themselves and by pressure put on the state by civil society and movements:

If the movements and the civil society are strong, they can put pressure on the government to force the Revolutionary Guards to invest the capital and the wealth of the country in a productive way so that ordinary people can benefit from it. We know that billions of dollars have disappeared and we want these to be invested in the interest of the people. The increasing numbers of private banks lend money with high interests to people and especially the poor people. These should be controlled. But this can only be done if the civil society and movements have a voice and can raise their voices.

Despite the fact that they are in favour of international cooperation, they argued that the crisis facing the region, in addition to neo-liberalism and rising poverty levels have made it much more difficult for activists to organise and build strong movements that could oppose the policies of the state:

The civil society and the movements which were suppressed under Ahmadinejad have not found the opportunity to mobilise and raise their voices. Unfortunately the regional conflicts have forced Iran to military mobilisation and this once again weakens the civil society and the movements. Militarism is growing and this external factor is threatening the social movements.

3 Privatisation programs took place after the end of the Iran-Iraq war in 1989. Both the Rafsanjani administration (1989-1997) and the Khatami administration (1997-2005) were involved in privatising industries that had been nationalised during the revolution. This interview participant argues that during Ahmadinejad's administration (2005-2013) the Revolutionary Guard became a major beneficiary of privatisation. 
It is important to note, however that women are not passive in these processes and continue to press for change in an increasingly uncertain and difficult political and economic climate:

We feel that we have been and we are walking on a dangerous bridge which could collapse any minute so we have learned where to hold our hands so that we will survive and continue. We have learned and experienced hard work. We have learned intellectualism, i.e., looking critically at the world, and this has come not from the intellectuals but from the ordinary people and their experiences. We feel that our society accepts gender equality, but our laws and regulations do not. But we are trying to make that right too in our own way and according to our culture.

\section{Conclusions}

In this article, I have argued that Iranian women activists welcome international support and solidarity particularly in the form of building activist links across borders. However, their views of the support of Western individuals and organisations are complicated by their experience of Western foreign policy of the past three decades that has made it more difficult for women to organise. Working class and Middle class women have been detrimentally impacted by the sanctions regime, which has harmed ordinary Iranians and by neo-liberal policies which enriched a conservative political elite with connections to the regime, at the expense of the majority of the population. This 'lived experience' of Western foreign policy has produced debates about the benefits and challenges posed by transnational cooperation in Iran. In much of the literature on transnational cooperation, outside links are seen to be positive, enabling activists to gain knowledge and resources from overseas. This is particularly the case in writing on international feminist networks, which tends to focus on linkages between institutionalised, top-down and hierarchical organisations. In this article, I have sought to present a more complex picture of the politics of transnational activism, in which Iranian women activist's views of transnationalism are intimately linked to their experience of Western foreign policies which have made it more difficult for women to challenge patriarchal laws and conservative forces. In addition to everyday material constraints, campaigns around gender and sexuality have been harmed by the discourse that Middle Eastern societies are conservative religious societies that need to be 'liberated' by the West. It is not surprising therefore that women's groups in Iran are at pains to point out that they are independent from international agencies and groups. They are critical of the actions of international NGO's, human rights and women's rights organisations and the attempt to incorporate them into a Western democracy promotion agenda.

The limitations and pitfalls of transnational solidarity outlined in this paper do not connote a conflict between the local concerns of indigenous, non-Western groups against that of globally interconnected transnational organisations, but rather the fact that women's organisations are impacted by global, as well as regional, conflicts and their ramifications, as are women across the globe. The politics of Iranian women activists are both linked into transnational networks and take place in the context of a challenging international environment.

Conflicts of Interest: The author declares no conflict of interest.

\section{References}

1. Nayereh Tohidi. “The Women's Movement and Feminism in Iran: A Glocal Perspective." In Women's Movements in the Global Era: The Power of Local Feminisms. Edited by Amrita Basu. Boulder: Westview Press, 2010, pp. 375-414.

2. Valentine Moghadam. Globalizing Women: Transnational Feminist Networks. Baltimore: The John Hopkins University Press, 2005.

3. Nancy A. Naples. "The Challenges and Possibilities of Transnational Feminist Praxis." In Women's Activism and Globalization: Linking Local Struggles and Transnational Politics. Edited by Nancy A. Naples and Manisha Desai. New York: Routledge, 2002, pp. 267-81. 
4. Nayereh Tohidi. "International Connections of the Iranian Women's Movement." In Iran and the Surrounding World: Interactions in Culture and Cultural Politics. Edited by Nikki R. Keddie and Rudolph P. Matthee. Seattle: University of Washington Press, 2002, pp. 205-28.

5. Haleh Esfandiari. Reconstructed Lives: Women and Iran's Islamic Revolution. Baltimore: The John Hopkins University Press, 1997.

6. Ziba Mir Husseini, and Richard Tapper. Islam and Democracy in Iran: Eshkevari and the Quest for Reform. London: IB Tauris, 2006.

7. Valentine Moghadam. Modernising Women, Gender and Social Change in the Middle East. Boulder and London: Lynne Rienner, 2003.

8. Haideh Moghissi. Feminism and Islamic Fundamentalism: The Limits of Postmodern Analysis. Pakistan: Oxford University Press, 2000.

9. Elaheh Rostami-Povey. Women, Work and Islamism, Ideology and Resistance in Iran. London: Zed Books, 2010.

10. Elaheh Rostami-Povey. “Women's Education and Employment in Iran.” In Gender and Race Matter: Global Perspectives on Being a Woman. Edited by Shaminder Takhar. Bingley: Emerald Publishing, 2015.

11. Khadijeh Aryan. "The Boom in Women's Education." In Women, Power and Politics in 21st Century Iran. Edited by Tara Povey and Elaheh Rostami Povey. Farnham: Ashgate Publishing, 2012, pp. 169-82.

12. Roksana Bahramitash. Gender and Entrepreneurship in Iran: Microenterprise and the Informal Sector. New York: Palgrave MacMillan, 2013.

13. Tara Povey. Social Movements in Egypt and Iran. London: Palgrave, 2015.

14. Parvin Paidar. Women in the Political Process in Twentieth Century Iran. Cambridge: Cambridge University Press, 1995.

15. Roksana Bahramitash, and Hadi Salehi Esfahani. “Nimble Fingers No Longer! Women's Employment in Iran." In Contemporary Iran: Economy, Society, Politics. Edited by Ali Gheissari. Oxford: Oxford University Press, 2009, pp. 77-122.

16. Amir Mehyar, Gholamadi Farjadi, and Mohammad Tabibian. "Labor-Force Participation of Women in Contemporary Iran." In Women in Iran from 1800 to the Islamic Republic. Edited by Lois Beck and Guity Nashat. Chicago: University of Illinois Press, 2004, pp. 182-203.

17. Afsaneh Najmabadi. "(Un)veiling Feminism." Social Text 18 (2000): 29-45. [CrossRef]

18. Mahnaz Afkhami. "Iranian Women's One Million Signatures Campaign: The Inside Story, Forward." 26 October 2009. Available online: http:/ / www.mahnazafkhami.net/2009/iranian-womens-one-millionsignatures-campaign-for-equality-the-inside-story-foreword/ (accessed on 20 June 2016).

19. Carla Power. “The Women of Iran's One Million Signatures Campaign: The Activists.” Glamour Magazine, 2 November 2009. Available online: http:/ / www.glamour.com/story/the-women-of-irans-one-millionsignatures-campaign (accessed on 20 June 2016).

20. Assieh Amini. “Stop Stoning Forever Campaign." Violence Is Not Our Culture, 16 January 2008. Available online: http://www.violenceisnotourculture.org/content/stop-stoning-forever-campaign (accessed on 20 June 2016).

21. Elahe Amani. "A Rare Victory for Women's Rights in Iran." Open Democracy, 28 March 2008. Available online: https:/ / www.opendemocracy.net/article/dg_asg (accessed on 20 June 2016).

22. Farid Marjai, and Mehrnaz Shahabi. "'Iranian Mothers for Peace' Alert the World on Sanctions and Shortage of Medicines." Monthly Review Zine, 1 February 2013. Available online: http:/ /mrzine.monthlyreview.org/ 2013/ms010213.html (accessed on 20 June 2016).

23. Margaret E. Keck, and Kathryn Sikkink. Activists beyond Borders, Advocacy Networks in International Politics. Ithaca: Cornell University Press, 1998.

24. Luis Eduardo Guarnizo, and Michael Peter Smith. "The Locations of Transnationalism." In Transnationalism From Below. Edited by Michael Peter Smith and Luis Eduardo Guarnizo. New Brunswick: Transaction Publishers, 1998, pp. 3-31.

25. Donatella della Porta, and Sidney Tarrow. "Transnational Processes and Social Actvism: An Introduction." In Transnational Protest and Global Activism: People, Passions and Power. Edited by Donatella della Porta and Sidney Tarrow. Oxford: Rowman and Littlefield, 2005, pp. 1-17.

26. Sidney Tarrow. The New Transnational Activism. Cambridge: Cambridge University Press, 2005.

27. Mark Lynch. "Blogging the New Arab Public." Arab Media and Society 1 (2007): 1-29. 
28. Sally J. Scholz. "Transnational Feminist Solidarity and Lessons from the 2011 Protests in Tahrir Square." Global Discourse 4 (2014): 205-19. [CrossRef]

29. Sidney Tarrow. Power in Movement: Social Movements, Collective Action and Politics. Cambridge: Cambridge University Press, 2011.

30. Judith Butler. "Restaging the Universal: Hegemony and the Limits of Formalism." In Contingency, Hegemony, Universality: Contemporary Dialogue on the Left. Edited by Judith Butler, Ernesto Laclau and Slavoj Žižek. London: Verso, 2000, pp. 11-43.

31. Carol C. Gould. "Varieties of Global Responsibility, Social Connection, Human Rights and Transnational Solidarity." In Dancing with Iris: The Philosophy of Iris Marion Young. Edited by Ann Ferguson and Mechthild Nagel. New York: Oxford University Press, 2009, pp. 185-97.

32. Chandra Talpade Mohanty. Feminism without Borders: Decolonizing Theory, Practicing Solidarity. Durham: Duke University Press, 2003.

33. Caren Kaplan. "The Politics of Location as Transnational Feminist Practice." In Scattered Hegemonies: Postmodernity and Transnational Feminist Practices. Edited by Inderpal Grewal and Caren Kaplan. Minneapolis: University of Minnesota Press, 1994, pp. 137-52.

34. Elspeth Probyn. "Travels in the Postmodern: Making Sense of the Local." In Feminism/Postmodernism. Edited by Linda J. Nicholson. New York: Routledge, 1990, pp. 176-89.

35. Maha Abdelrahman. "The Transnational and the Local: Egyptian Activists and Transnational Protest Networks." British Journal of Middle Eastern Studies 38 (2011): 407-24. [CrossRef]

36. Lila Abu-Lughod. “Do Muslim Women Really Need Saving? Anthropological Reflections on Cultural Relativism and Its Others." American Anthropologist 104 (2002): 783-90. [CrossRef]

37. Roksana Bahramitash. "The War on Terror, Feminist Orientalism and Orientalist Feminism: Case Studies of Two North American Bestsellers." Critique: Critical Middle Eastern Studies 14 (2005): 223-37. [CrossRef]

38. Nicola Pratt. "The Queen Boat Case in Egypt: Sexuality, National Security and State Sovereignty." Review of International Studies 33 (2007): 129-44. [CrossRef]

39. Joseph Massad. "Re-Orienting Desire: The Gay International and the Arab World." Public Culture 14 (2002): 361-85. [CrossRef]

40. Janet Afary. Sexual Politics in Modern Iran. Cambridge: Cambridge University Press, 2009.

41. Kathryn Babayin, and Afsaneh Najmabadi, eds. Islamicate Sexualities Studies: Translations across Temporal and Geographical Zones of Desire. Cambridge: Harvard University Press, 2007.

42. Sahar Amer. "Naming to Empower: Lesbianism in the Arab Islamicate World Today." Journal of Lesbian Studies 16 (2012): 381-97. [CrossRef] [PubMed]

43. Mahnaz Afkhami, and Erika Friedl. "Introduction." In Muslim Women and the Politics of Participation: Implementing the Beijing Platform. Edited by Mahnaz Afkhami and Erika Friedl. Syracuse: Syracuse University Press, 1997, pp. xi-xx.

44. Joel Beinin. "Neo-liberal Structural Adjustment, Political Demobilization and Neo-authoritarianism in Egypt." In The Arab State and Neo-Liberal Globalization: The Restructuring of State Power in the Middle East. Edited by Laura Guazzone and Daniela Pioppi. Reading: Ithaca Press, 2009, pp. 19-46.

45. Timothy Mitchell. Rule of Experts: Egypt, Techno-Politics, Modernity. Berkeley: University of California Press, 2002.

46. Tara Povey. "The Women's Movement and Neo-Liberalism in Iran: Between Accommodation and Resistance." In Gender and Race Matter: Global Perspectives on Being a Woman. Edited by Shaminder Takhar. Bingley: Emerald Publishing, 2015.

47. Ali Ansari. "The Revolution Will Be Mercantilized." The National Interest 105 (2010): 50-60.

48. Najmeh Bozorgmehr. "Private Banks Open to Assist Tehran Insiders." The Financial Times, 9 May 2011. Available online: http://www.ft.com/cms/s/0/ebcda530--7a5a-11e0-af64-00144feabdc0. html\#axzz3eXLJObrc (accessed on 20 June 2016).

(C) 2016 by the author; licensee MDPI, Basel, Switzerland. This article is an open access article distributed under the terms and conditions of the Creative Commons Attribution (CC-BY) license (http://creativecommons.org/licenses/by/4.0/). 